\title{
Optimizing a prandial insulin dosing in patients with type 1 diabetes
}

\section{ABSTRACT}

Intensive functional insulin therapy (FIT) relies on an algorithm for counting carbohydrate exchanges (CE) developed in the 1980s. With this method, patients with type 1 diabetes can tailor an insulin dose themselves depending on the amount of carbohydrates taken with food. However, it has been proven that proteins and fats affect the level of after-meal glycaemia and insulin secretion. This is caused by such factors as delayed gastric emptying and the involvement of proteins and fats in gluconeogenesis. To consider proteins and fats taken in meals, the concept of protein and fat exchanges (PFE) has been developed, which can be taken into account when calculating a prandial insulin dose. The aim of this paper is to explain various methods for intensive insulin therapy in patients with type 1 diabetes, treated either with continuous subcutaneous insulin infusion or with multiple dose injection. (Clin Diabet 2015; 4, 6: 243-250)

Key words: diabetes mellitus type 1, intensive functional therapy, carbohydrate exchanger, protein and fat exchanger

\section{Introduction}

The discovery of insulin in 1921 by Banting, Best et al. was undoubtedly a breakthrough in the treatment of patients with type 1 diabetes [1]. Since then, during over 90 years of insulin therapy, new insulin preparations have appeared and treatment regimens

\footnotetext{
Address for correspondence:

dr n. med. Karolina Jabłońska

ul. Siedlecka 2, 72-010 Police

Phone/fax: +484253858

e-mail: karolinaannajablonska@gmail.com

Clinical Diabetology 2015, 4, 6, 243-250

DOI: $10.5603 / D K .2015 .0032$
}

Translation: GROY Translations have undergone constant modifications. The relatively short half-life of the first insulin preparations led to their multiple administration throughout the day. Together with the appearance of protamine zinc insulin (in the 1930s) as it is in the case of semilente, lente and ultralente insulin the possibility of reducing the number of injections of insulin to one or two a day become a reality. Monocomponent insulins, shortacting human insulins and the most recent fast-acting analogs produced in subsequent years allowed for gradual intensification of treatment. It is worth noting that back in the 1980s there was a fairly widespread view that the development of chronic diabetes complications was influenced by factors unrelated to the degree of metabolic control [2]. A clear turning point in the approach to insulin therapy occurred in 1993 with the publication of results of the DCCT study - in which, during a 6.5-year observation of over 1400 patients with type 1 diabetes, it was demonstrated that the use of intensive insulin therapy significantly reduces the risk of developing chronic microvascular and neuropathic complications [3]. It was shown that not only hyperglycemia, but also glycemia variations are an important pathogenic factor in the development of microangiopathic complications [4]. The amplitude of glycemic fluctuations correlates with the number of free radicals, which are some of the main factors responsible for the formation of vascular complications, better than the average daily glycemia or $\mathrm{HbA}_{1 \mathrm{c}}$ [5]. It has been shown that postprandial hyperglycemia may be a better prediction factor of the progression of the disease and its chronic complications than, for example, fasting glycemia or glycated hemoglobin $\mathrm{HbA}_{1 \mathrm{c}}$ [6-8].

\section{Methods for selecting postprandial insulin dose in type 1 diabetes Functional intensive insulin therapy}

Currently, the primary method for the treatment of patients with type 1 diabetes is functional intensive 
insulin therapy (FIT) [9]. It is carried out with the use of multiple subcutaneous injections of insulin, or with the use of personal insulin pumps (PIP). Patients treated with the use of injectors require two types of insulin: basal insulin (isophane long-acting or long-acting analogue) and prandial insulin (fast-acting analog or short-acting human insulin). The dose of basal insulin should be approx. 30-40\% of the total daily need for insulin and when selected properly it does not require frequent modifications [10,11]. In contrast, postprandial doses depend on the composition, size and time of the consumed meal, as well as on the planned physical activity and current blood glucose level [12]. The above observations formed the basis for the improvement of methods for selection of the prandial insulin dose and intensified research on the influence of various nutritients on postprandial glycemia value.

\section{Rating carbohydrate content \\ Carbohydrate exchanges}

The fact that in the case of people with type 1 diabetes there is no insulin secretion means that the amount of carbohydrates contained in food has a huge impact on postprandial glycemia. Fixed doses of insulin administered with meals would require a constant amount of consumed carbohydrates. Otherwise, the risk of hypoglycemia or significant postprandial hyperglycemia would rise. The active lifestyle of young people with type 1 diabetes and consent to a more liberal diet require the administration of varying doses of insulin, adapted both to consumed carbohydrates and the patient's activity.

The initiation of intensive insulin therapy can be traced back to the mid-twentieth century, when the pediatrician Karl Stolte educated his patients in monitoring the concentration of glucose in urine before each main meal, and also in regulating the insulin dose depending on the result obtained and the amount of carbohydrates that they planned to eat [13]. At the beginning of the 1980s, Jean-Philippe Assal from Geneva and Michael Berger from Düsseldorf created a 5-day training system for patients with type 1 diabetes which aimed to involve patients in the therapeutic process $[13,14]$. At the same time, the NIS program was created (near-normoglycemic insulin substitution), which has become the basis of functional intensive insulin therapy. The propagator of the algorithm used in this method of treatment, which is based on the use of carbohydrate exchanges as the basic unit for calculating the dose of insulin administered with a meal, was Kinga Howorka [14]. The method developed by her allowed for flexible adjustment of insulin doses to the consumed meal, physical activity and individual needs.
In this method, the basis for determining prandial insulin dose is the amount of carbohydrates $(\mathrm{g}$ ) contained in a planned meal and the index of insulin sensitivity, modified with a correction dose resulting from the value of preprandial blood glycemia. The amount of consumed carbohydrates is expressed in the form of carbohydrate exchangers (CE), where 1 CE corresponds to $10 \mathrm{~g}$ of consumed carbohydrates [in the UK $1 \mathrm{CP}$ (Carbohydrate Portion) - $10 \mathrm{~g}$ of carbohydrates, in German-speaking countries 1 KE (Kohlenhydrateinheit) - $12 \mathrm{~g}$ of carbohydrates, in the United States 1 CS (Carbohydrate Serving) - $15 \mathrm{~g}$ of carbohydrates) $[15,16]$. According to the guidelines of some Diabetic Societies (e.g. in the United Kingdom) we can also adjust the insulin converter directly to the amount of carbohydrates in grams [16]. Determination of the insulin dose is made by the patient himself, with prior education. There is evidence that the therapy conducted in this way is safe, improves living comfort and may have a beneficial effect on anthropometric indicators such as BMI or waist circumference [17]. Although FIT is a common, accepted and apparently optimal method of therapy, meta-analyses of previous studies show only slight differences in the degree of diabetes control among patients who calculate the amount of carbohydrates and patients who administer fixed doses of prandial insulin [17-19]. Differences in $\mathrm{HbA}_{1 \mathrm{c}}$ in the FIT group in relation to the control group ranged from -0.35 to $-0.64 \%$, thus indicating the need to find new algorithms for calculating prandial insulin doses.

\section{Glycemic index and load}

It is known that under physiological conditions the secretion of insulin is affected not only by the amount of consumed carbohydrates, but also by their quality. In the 1980s the term of glycemic index (GI) was introduced, which illustrates the differences in postprandial glycemia after consuming the same amount of carbohydrates contained in various products with different properties $[20,21]$. Glycemic index is defined as the percentage of increase in blood glucose level after consumption of a product containing $50 \mathrm{~g}$ of digestible carbohydrates in comparison with standart glycemia after consumption of $50 \mathrm{~g}$ of glucose (value $100 \%)$. It is recognized that products with low and medium glycemic index are those whose $\mathrm{Gl}$ is less than $60 \%$. Tables showing the Gl of carbohydrate products are widely available and allow the patient to choose a product after the consumption of which the increase of glycemia, and thus also the need for insulin, will be smaller. A related value is the glycemic load (GL), which is the product of $\mathrm{Gl}$ and the amount of consumed carbohydrates divided by 100 . The use of a diet 
consisting of products with a low glycemic index and low glycemic load by healthy individuals is associated with a lower postprandial insulin secretion, a lower risk of developing diseases such as type 2 diabetes, cardio-vascular diseases or cancer (e.g. breast cancer, gallbladder cancer) and improving metabolic control in cases of previously diagnosed type 2 diabetes [22-24]. Consumption of products with a low glycemic index results in absorption of glucose which is slow and evenly distributed over time, and consequently reduces the risk of postprandial hyperglycemia [25].

\section{Insulin index}

Glucose is not the only factor influencing the value of glycemia and insulin level in the blood. Others include fructose, mannose, selected amino acids and short chain fatty acids $[26,27]$. Under physiological conditions, meals which are both high-fat and rich in protein cause a significant increase in postprandial insulin level, which should be taken into account when calculating the prandial dose [28-30]. On the basis of these observations, a group of Australian scientists has created the concept of the insulin index (FII, Food Insulin Index) [26]. They have developed a mathematical model on the basis of which the Fll of food products is determined according to the following equation:

FII $(\%)=$ area under the curve of 120-minute insulin concentration after consumption of the tested product (1000 kJ)/area under the curve of 120-minute insulin concentration after consumption of white bread (1000 kJ)

The above determinations were performed in a group of young, healthy persons with an average BMI of $22.7 \pm 0.4 \mathrm{~kg} / \mathrm{m}^{2}$. In the first phase Fll was determined for 38 basic foods available on the market divided into 6 groups: fruits, confectionery, snacks and sweets, products rich in proteins, products and cereals rich in carbohydrates. White bread was used as a reference point (FI $100 \%)$. The product group which received the highest FII (average 89\%) were snacks, including a chocolate bar, yogurt, ice cream, peanuts, chips, popcorn and jelly beans, although this group included products with the highest and lowest FII (jelly beans - $160 \%$, peanuts $20 \%$ ). At the same time, products with the same carbohydrate content, expressed in grams, varied considerably in terms of the value of Fll. Compared to the aforementioned jelly beans, fruits containing the same amount of carbohydrates were characterized by Fll of approx. $80 \%$. It was also noted that some of the products rich in protein and fat, such as eggs, beef, fish, lentils or cheese induced insulin secretion comparable to brown rice or whole-wheat bread. Also, significant differences in Fll between commonly consumed carbohydrate products such as potatoes and pasta were described (FII respectively $121 \%$ and $40 \%$ ). At the same time a positive correlation between FII and GL values was demonstrated [26]. A continuation of the above studies was the comparison of the effectiveness of estimating postprandial insulin secretion with the use of FII and GL after mixed meals containing carbohydrates, proteins and fats. After testing 13 isoenergetic meals containing $2000 \mathrm{~kJ}$ it was shown that FII best correlates with the actual concentration of insulin in the blood of the aforementioned [31]. An NIDDA study, with the use of a system for continuous monitoring of glycemia, compared the concentration of glucose in the case of patients with type 1 diabetes within 3 hours after consumption of a mixed meal, wherein the prandial dose was determined using two methods: on the basis of Fll and by the traditional method, taking into account only the amount of carbohydrates contained in a meal. It was shown that the method using Fll allows for a longer maintenance of postprandial glycemia within normal limits and to obtain a lower peak glucose concentration [32, 33]. With the use of this method postprandial glucose concentration returned to preprandial values more quickly. Calculation of the prandial insulin dose based on the FIl index is quite complex and in daily practice it seems to be difficult to implement.

\section{Consideration of proteins and fats} in a meal

Influence of consumed proteins and fats on the absorption of glucose

The effect of protein and fat content in the consumed meal on the absorption of glucose and maintenance of postprandial glucose has been known for a long time. It is associated mainly with the process of slowed gastric emptying [34-36]. The course of the above process is controlled by a number of hormones and neuromediators secreted under the influence of consumed meals. Hormonal factors responsible for slowing gastric emptying include cholecystokinin (CCK), secretin, glucagon, glucagon-like peptide-1 (GLP-1) and glucose-dependent insulinotropic peptide (GIP), among which CCK has the strongest inhibitory effect [37-39]. This hormone is secreted both under the influence of digest products (L-amino acids, polypeptides) as well as fats (fatty acids), which results in the fact that the more of these nutrients are in the consumed meal, the slower is the passage of digested food from the stomach into the duodenum $[37,40]$. In case of patients with type 1 diabetes, dysregulations of postprandial glucagon secretion are observed, caused by an absolute deficiency of 
endogenous insulin. After a meal rich in protein there is a secretion of this hormone, which leads to an increased release of glucose from the liver into the blood stream and reduction of consumption of glucose in metabolic processes and this consequently contributes to increased postprandial hyperglycemia [41].

One of the studies conducted in a group of patients with type 1 diabetes compared concentrations of glucose in the blood and the need for insulin 5 hours after consumption of three different meals: standard, rich-in-proteins and high-fat [42]. A significantly greater increase in glucose concentration was observed after a meal rich in protein during the last 150 minutes of the study. After a high fat meal, during the first 90 minutes lower glycemia values were observed compared to a standard and rich-in-protein meal, while in the subsequent intervals glycemia values were similar to the results obtained after consumption of a standard meal. This was probably associated with the aforementioned delayed gastric emptying, and consequently slower absorption of glucose into the bloodstream [43]. Wolpert et al., in a longer observation compared glycemia levels in a group of patients with type 1 diabetes after two meals consumed at dinner: low- and high-fat containing the same amount of carbohydrates [44]. They found that a high fat meal required more insulin; postprandial glycemia remained at a higher level and required additional administration of insulin doses up to 10 hours after the test meal.

\section{Protein and fat exchanges}

A method that allows us to take into account the amount of proteins and fats when choosing the prandial dose of insulin was developed for patients using insulin pumps in the Institute of Mother and Child in Warsaw [45]. It is based on counting protein-fat exchanges (PFE), where 1 PFE is equivalent to $100 \mathrm{kcal}$ coming from proteins and fats. It was assumed that the amount of insulin per 1 PFE is equal to the amount of insulin administered per $1 \mathrm{CE}$, but the above dosage decays with time in proportion to the amount of consumed PFE $[45,46]$. It has been shown that the use of this method in a group of pediatric patients is associated with the improvement of glycemic control after a meal rich in protein and fat (pizza) [47]. Studies in a group of adults show a reduced need for insulin per 1 PFE (30-50\% of the dose per $1 \mathrm{CE})$ [48].

\section{Selection of the prandial dose of insulin in a group of patients with type 1 diabetes treated with the use of personal insulin pumps}

The proper insulin therapy that respects both the amount of carbohydrates and proteins and fats is pos- sible in a group of patients treated with the use of a personal insulin pump (PIP). Pump therapy gives us the opportunity to administer three types of prandial bolus: simple bolus, preferred before meals rich in carbohydrates; square bolus, administered for several hours and used mainly for protein-fat meals; and dualwave bolus intended for mixed meals wherein a portion of insulin is administered right away, with the rest in a time frame programmed by the patient and adapted to the amount of consumed proteins and fats [49]. The amount of protein-fat exchanges is administered in the form of a square bolus calculated according to the rule: the number of PFE $+2 \mathrm{~h}$. The time, however, should not be longer than 7 hours, as this may lead to remote postprandial hypoglycemia [48]. Patients who for various reasons do not want to agree to additional difficulties related to the calculation of PFE, can be advised to administer with mixed meals a dose of insulin increased by $30 \%$ compared to the dose calculated according to the amount of carbohydrates and to administer this part as a square bolus [49]. Many studies have shown the beneficial effect of a dual-wave bolus on postprandial glycemia regardless of the time of observation (from 3 to up to 14 hours after a meal) [50-52]. However, there are reports in which there were no differences in postprandial glycemia after a high fat meal, irrespective of the type of bolus: simple, dual-wave or square [53]. The influence of protein on the value of postprandial glycemia remains the subject of an ongoing debate. In the study of Gawrecki et al., which was conducted in a group of patients with type 1 diabetes treated with the use of PIP it was shown that a meal consisting only of protein and fat also requires the administration of insulin [48]. It was observed that after consumption of 7 PFE, glycemia levels after the meal were significantly lower in patients who administered insulin in a dose of 0.5 u./1 PFE in the form of a square bolus over 8 hours, compared with the glycemia of patients who did not administer insulin at all. The influence of protein on the value of postprandial glycemia and prandial need for insulin is questioned by Klupa et al. [54]. In the cited study, 10 patients with type 1 diabetes treated with the use of personal insulin pumps consumed a meal consisting only of proteins $(0.3 \mathrm{~g}$ of preparation Protifar/kg of body weight) and glycemia levels were recorded within a time of 6 hours after the meal using the CGM and compared with glycemia during a six-hour period of refraining from eating. There were no significant differences between glycemia values in the first five hours. Higher glycemia levels were recorded only in the sixth hour after a protein meal. Results of the study may suggest the possibility of consumption 
of protein meals by patients with type 1 diabetes without the need to administer prandial insulin.

In the study of Smart et al. the behavior of glycemia after meals containing different amounts of protein and fat in combination with the same amount of carbohydrates was analyzed [55]. Over four consecutive days, patients with type 1 diabetes (children and teenagers) consumed meals containing $30 \mathrm{~g}$ of carbohydrates and one of four combinations: $4 \mathrm{~g}$ of fat and $5.3 \mathrm{~g}$ of protein (low-fat/low-protein meal), $3.9 \mathrm{~g}$ of fat and $40 \mathrm{~g}$ of protein (low-fat/high-protein meal), $35 \mathrm{~g}$ of fat and $5.3 \mathrm{~g}$ of protein (high-fat/low-protein meal) and $35.2 \mathrm{~g}$ of fat and $40 \mathrm{~g}$ of protein (high-fat/high-protein meal). The observation time was 5 hours and values of glycemia were recorded by means of CGM. Insulin was administered with each meal calculated on the basis of the conversion insulin/CE. It was shown that glycemia after eating a high-protein or a high-fat meal was significantly higher in comparison to a low-protein and low-fat meal. A meal rich in protein and fat resulted in significantly greater increase of glycemia in comparison to all other meals. At some time points analyzed during the study the increase of glycemia was the sum of the increase of glycemia only after a high-protein or high-fat meal. In the presented study, statistically significant differences in glycemia levels were observed after $120 \mathrm{~min}$. Smart et al. drew a conclusion about the protective effect of proteins with respect to postprandial hypoglycemia episodes that were observed the least frequently after a meal with a high protein content (both high and low fat content). The authors of the cited study observed the most frequent hypoglycemic episodes after eating a carbohydrate meal with a low content of protein and fat.

In the study of Pańkowska et al., in which metabolic control was evaluated in a group of 499 pediatric patients treated with the use of PIP, and on the basis of analysis of the data from 2-week reports of reading the data from insulin pumps, it was demonstrated that patients using square and dual-wave boluses in the amount of two or more per day achieve a lower percentage of glycosylated hemoglobin compared to those who use these types of boluses less frequently than once a day [56]. However, the composition of different meals where the above types of boluses were adiministered was not analysed, but the focus was placed on an assessment of the degree of use of the technical possibilities offered by this method of treatment. A similar analysis concerning adults was conducted by Klupa et al. in a group of 56 patients [57]. In this group of patients more frequent use of dual-wave boluses (> 20\%/day vs < $20 \%$ /day) was associated with a lower percentage of glycated hemoglobin. It has also been shown that this type of bolus is more often used by men and patients with a shorter duration of diabetes. In another study, conducted by the aforementioned pediatric center, glycemia levels were compared in a group of 26 patients within 6 hours of the consumption of a meal rich in protein and fat (pizza) depending on the applied prandial bolus (square bolus vs. simple bolus) [47]. It has been shown that administration of a square bolus for 6 hours is associated with a higher postprandial glycemic control. Similar results indicating the superiority of a square bolus for meals such as pizza have been obtained by other authors $[50,51,58]$. Different results have been presented by De Palma et al., who in a group of 38 children assessed glycemia during 6 hours after consumption of a "margherita" pizza, and in subsequent days insulin was administered with a meal according to one of the following combinations: square bolus 30/70\% administered 15 minutes before a meal and programmed for 6 hours; identical bolus administered immediately before a meal; simple bolus administered 15 minutes before a meal; and simple bolus administered immediately before a meal [59]. The best glycemic control was achieved after the administration of a simple bolus 15 minutes before a meal. The authors explained this as the result of a relatively low fat content $(23 \%)$ in the applied meal.

Taking into account the complexity of functional intensive insulin therapy, in daily practice emphasis is put on the individualization of therapy depending on the preferences and intellectual abilities of the patient. This procedure prevents the reduction of comfort and quality of life, and minimizes the risk of negligence in the form of avoidance of boluses or lack of self-control, which may lead to worse metabolic control of diabetes [60-62]. According to the opinion of the American Diabetes Association (ADA) education should be provided in calculating the amount of carbohydrates in consumed meals [63]. At the same time, in accordance with the above recommendations, education in calculating the calories from proteins and fats should only be provided in the case of those patients who estimate the amount of carbohydrates during the calculation of a prandial insulin dose in a proficient way [63-65]. In the guidelines of the Canadian Diabetes Association (CDA) it is recommended to take into account the amount of consumed carbohydrates and their glycemic index in the designation of the prandial dose of insulin; there is no reference to the amount of consumed proteins and fats [66]. In accordance with the recommendations of the Polish Diabetes Association (PDA) the ability to independently modify the dose, depending on the caloric content of a meal is an essential part of therapy in the case of patients with type 1 diabetes 
and should include the method of calculating both carbohydrate exchanges and protein-fat exchanges [9]. However, there is no precise guidance on how to assess the need for insulin depending on the amount of consumed proteins and fats.

\section{Prandial insulin dose adjustment in patients with type 1 diabetes treated with the use of injectors}

Most patients treated with the FIT method use insulin analogues whose peak of activity falls within 30-120 $\mathrm{min}$, and whose total operation time does not exceed four hours [27]. Patients treated with these insulins are generally recommended to administer a bolus immediately before a meal [67-69]. However, we can modify the time of administration of insulin according to the qualitative composition of the planned meal, so as to match the peak of activity of insulin to the absorption peak of glucose from the gastrointestinal tract. Meals rich in products with a high glycemic index require administration of insulin some time before the planned meal and the conversion insulin/ /CE should be greater than in the case of products with a low GI [70]. Meals consisting mostly of carbohydrates with a low glycemic index come with insulin typically administered immediately before the meal, and meals rich in proteins and fats come with insulin administered during the meal, which is associated with the expected delay of postprandial glycemia peak [49]. Adjusting the time of administration of prandial insulin in such way, although it complicates the course of therapy, may decrease the risk of postprandial hyperglycemia. On the other hand, after a meal rich in proteins and fats, due to the emerging hyperglycemia patients often are forced to administer an extra dose of analogue insulin several hours after a meal. A solution could be to take into account both carbohydrates and proteins and fats in the calculation of the prandial insulin dose and to administer it in one injection corresponding to the simple bolus applicable in PIP therapy [71]. Due to the lack of the possibility of staggering the extra portion of insulin and what goes with it - probably a greater risk of hypoglycemia, the converter insulin/PFE should, however, be less than the suggested $50 \%$ of the value of converter insulin/CE in a group of adult patients treated with PIP.

\section{Dietary guidelines}

When discussing methods for selection of the prandial insulin dose, we should also mention dietary guidelines that in the context of the spreading epidemic of obesity, even in a younger group of patients, are beginning to be increasingly important in the conduct of therapy [49]. In accordance with the recommendations of the Polish Diabetes Association, the content of carbohydrates in a daily diet should be between $40-50 \%$, with a clear predominance of products with a low glycemic index and simple carbohydrates restriction. Fats should constitute $30-35 \%$ of the total energy value in a diet, and proteins $15-20 \%$. In addition, the quality and quantity of proteins and fats should be adapted to the known chronic complications of diabetes and concomitant diseases [9].

\section{Summary}

Values of postprandial glycemia are of crucial importance in daily therapy and in achieving long-term therapeutic goals $[6,72-74]$. As a parameter evaluated by each patient several times a day, it appears to be an easily accessible factor enabling modification of treatment. However, we should not forget that the degree of control of diabetes consists of a number of other factors, such as socioeconomic status, age, quality of self-control and even marital status [75]. Still, despite the emphasis put on the intensification of therapy in patients with type 1 diabetes, the average survival in this group is significantly lower compared with the general population [76-78]. This fact should be a continuous motivation to seek for methods of improving insulin therapy that are more precise, and at the same time accepted by patients.

\section{REFERENCES}

1. Banting FG, Best $\mathrm{CH}$, Collip JB et al. Pancreatic extracts in the treatment of diabetes mellitus: preliminary report. Can Med Assoc J 1922: 12: 141-146.

2. Rosenstock J, Raskin P. Diabetes and its complications: blood glucose control vs. genetic susceptibility. Diabetes Metab Rev 1988; 4: 417-435.

3. The Diabetes Control and Complications Trial Research Group. The effect of intensive treatment of diabetes on the development and progression of long-term complications in insulin-dependent diabetes mellitus. N Engl J Med 1993; 329: 977-986.

4. The Writing Team for the Diabetes Control and Complications Trial/Epidemiology of Diabetes Interventions and Complications Research Group. Effect of Intensive Therapy on the Microvascular Complications of Type 1 Diabetes Mellitus. JAMA 2002; 287: 2563-2569.

5. Monnier L, Mas E, Ginet $\mathrm{C}$ et al. Activation of oxidative stress by acute glucose fluctuations compared with sustained chronic hyperglycemia in patients with type 2 diabetes. JAMA 2006; 295: 1681-1687

6. Temelkova-Kurktschiev TS, Koehler C, Henkel E et al. Postchallenge plasma glucose glucose and glycemic spikes are more strongly associated with atherosclerosis than fasting glucose oraz $\mathrm{HbA}_{1 \mathrm{c}}$ level. Diabetes Care 2000; 23: 1830-1834.

7. The relationship of glycemic exposure $(\mathrm{HbA} 1 \mathrm{c})$ to the risk of development and progression of retinopathy in the diabetes control and complications trial. Diabetes 1995; 44: 968-983.

8. Heptulla RA, Allen HF, Gross TM, Reiter EO. Continuous glucose monitoring in children with type 1 diabetes: before and after insulin pump therapy. Pediatric Diabetes 2004; 5: 10-15.

9. Zalecenia kliniczne dotyczące postępowania u chorych na cukrzycę. Stanowisko Polskiego Towarzystwa Diabetologicznego. Diabetologia Kliniczna 2015; 4 (Suppl A). 
10. Czupryniak L (ed). Diabetologia. Kompendium. Wydanie I. Termedia Wydawnictwa Medyczne, Poznań 2014; 99-123.

11. Strojek K (ed). Diabetologia. Praktyczny poradnik. Wydanie III uzupełnione i uaktualnione. Termedia Wydawnictwa Medyczne, Poznań 2014; 89-108.

12. Moczulski D (ed.). Wielka Interna. Diabetologia. Medical Tribune Polska, Warszawa 2010; 84-95.

13. Mühlhauser I, Jörgens $V$, Berger $M$ et al. Bicentric evaluation of a teaching and treatment progamme for type 1 (insulin-dependent) diabetic patients: improvement of metabolic control and other measures of diabetes care for up to 22 months. Diabetologia 1983; 25: 470-476.

14. Howorka K. Funkcjonalna insulinoterapia. $\alpha$-medical Press, Bielsko-Biała 1996.

15. Kulkarni KD. Carbohydrate counting: a practical meal-planning option for people with diabetes. Clinical Diabetes 2005; 23; 3: 120-122.

16. Edward J, Harrison Z, Jackson P et al. Carbs Count. An introduction to carbohydrate counting and insulin dose adjustment [Internet]. London: Diabetes UK; 2011. Available from: https://shop.diabetes. org.uk/usr/downloads/A\%20Carbs-Count-2012-reducedsize.pdf

17. Laurenzi A, Bolla AM, Panigoni $G$ et al. Effects of carbohydrate counting on glucose control and quality of life over 24 weeks in adult patients with type 1 diabetes on continuous subcutaneous insulin infusion. Diabetes Care 2011; 34: 823-827.

18. Son O, Belgin E, Son NE et al. Investigation on carbohydrate counting method in type 1 diabetic patients. Biomed Res Int 2014; 2014: 176564. doi: 10.1155/2014/176564. Epub 2014 Aug 17.

19. Bell KJ, Barclay AW, Petocz P et al. Efficacy of carbohydrate counting in type 1 diabetes: a systematic review and meta-analysis. Lancet Diabetes Endocrinol 2014; 2: 133-140.

20. Wolever TMS, Jenkins DJA. The use of the glycemic index in predicting the blood glucose response to mixed meals. Am J Clin Nutr 1986; 43: 167-172.

21. Wolever TMS, Jenkins DJA, Jenkins AL, Josse RG. The glycemic index: methodology and clinical implications. Am J Clin Nutr 1991; 54: 846-854.

22. Salmeron J, Manson JE, Stampfer MJ et al. Dietary fiber, glycemic load, and risk of non-insulin-dependent diabetes mellitus in women. JAMA 1997; 227: 472-477.

23. Barclay AW, Petocz P, McMillan-Price J et al. Glycemic index, glycemic load, and chronic disease risk - a metaanalysis of observational studies. Am J Clin Nutr 2008; 87: 627-637.

24. Brand JC, Colagiuri S, Crossman S et al. Low-glycemic index foods improve long-term glycemic control in NIDDM. Diabetes Care 1991; 14: 95-101.

25. Liu A, Most M, Brashear $M$ et al. Reducing the glycemic index or carbohydrate content of mixed meals reduces postprandial glycaemia and insulinemia over the entire day but does not affect satiety. Diabetes Care 2012; 35: 1633-1637.

26. Holt SHA, Brand-Miller JC, Petocz P. An insulin index of foods: the insulin demand generated by $1000-k j$ portions of common foods. Am J Clin Nutr 1997; 66: 1264-1276.

27. Tatoń J, Czech A. Insulinoterapia cukrzycy oparta na patofizjologii - EBM. Termedia Wydawnictwa Medyczne, Poznań 2010; 153-171.

28. Simpson RW, McDonald J, Wahlqvist ML et al. Macronutrients have different metabolic effects in nondiabetics and diabetics. Am J Clin Nutr 1985; 42: 449-453.

29. Krezowski P, Nuttall FQ, Gannon MC, Bartosh NH. The effect of protein ingestion on the metabolic response to oral glucose in normal individuals. Am J Clin Nutr 1986; 44: 847-856.

30. Gannonn MC, Nuttall FQ, Westphal SA, Sequist ER. The effect of fat and carbohydrate on plasma glucose, insulin, C-peptide, and triglycerides in normal male subjects. J Am Coll Nutr 1993; 12: 36-41.

31. Bao J, De Jong V, Atkinson F et al. Food insulin index: physiologic basis for predicting insulin demand evoked by composite meals. Am J Clin Nutr 2009; 90: 986-992.
32. Bao J, Gilbertson HR, Gray R et al. Improving the estimation of mealtime insulin dose in adults with type 1 diabetes. Diabetes Care 2011; 34: 2146-2151.

33. Bell KJ, Gray R, Munns D et al. Estimating insulin demand for protein-containing foods using the food insulin index. Eur J Clin Nutr 2014; 1-5.

34. Feinle C, O'Donovan D, Doran S et al. Effects of fat digestion od apetite, APD motility, and gut hormones in response to duodenal fat infusion in humans. Am J Physiol Gastrointest Liver Physiol 2003; 284: G798-G807.

35. Moghaddam E, Vogt JA, Wolever TMS. The effects of fat and protein on glycemic response in nondiabetic humans vary with waist circumference, fasting plasma insulin, and dietary fiber intake. J Nutr 2006; 136: 2506-2511.

36. Phillips LK, Deane AM Jones KL et al. Gastric emptying and glycaemia in health and diabetes mellitus. Nat Rev Endocrinol 2015;11: 112-128.

37. Lan-Pidhainy $X$, Wolever TMS The hypoglycemic effect of fat and protein is not attenuated by insulin resistance. Am J Clin Nutr 2010; 91: 98-105.

38. Lodefalk M, Carlsson-Skwirut C, Holst JJ et al. Effects of fat supplementation on postprandial GIP, GLP-1, ghrelin and IGFBP-1 levels: a pilot study on adolescents with type 1 diabetes. Horm Res Paediatr 2010; 73: 355-362.

39. Hansen KB, Vilsboll T, Bagger Jl et al. Increased postprandial GIP and glucagon responses, but unaltered GLP-1 response after intervention with steroid hormone, relative physical inactivity, and high-calorie diet in healthy subjects. J Clin Endocrinol Metab 2011; 96: 447-453.

40. Traczyk W, Trzebski A (ed). Fizjologia człowieka z elementami fizjologii stosowanej i klinicznej. Wydanie trzecie. Wydawnictwo Lekarskie PZWL, Warszawa 2001; 721-800.

41. Sherr J, Tsalikian E, Fox $L$ et al. Evolution of abnormal plasma glucagon responses to mixed-meal feedings in youth with type 1 diabetes during the first 2 years after diagnosis. Diabetes Care 2014; 37: 1741-1744.

42. Peters A, Davidson MB. Protein and fat effects on glucose response and insulin requirements in subjects with insulin-dependent diabetes mellitus. Am J Clin Nutr 1993; 58: 555-560.

43. Lodefalk M, Aman J, Bang P. Effects of fat supplementation on glycaemic response and gastric emptying in adolescents with type 1 diabetes. Diabet Med 2008; 25: 1030-1035.

44. Wolpert HA, Atakov-Castillo A, Smith S, Steil GM. Dietary fat acutely increase glucose concentrations and insulin requirements in patients with type 1 diabetes. Diabetes Care 2013; 36: 810-816.

45. Pańkowska E. Ciągły podskórny wlew insuliny w terapii dzieci i młodzieży z cukrzycą typu 1. Diabetol Pol 2002; 9: 92-102.

46. Szypowska A, Pańkowska E, Lipka M. Guidelines concerning insulin dosage in children and adolescents with type 1 diabetes on continuous subcutaneous insulin infusion. Endokrynol Diabetol Chor Przemiany Materii Wieku Rozw 2006; 12: 45-50.

47. Pańkowska E, Błazik M, Groele L. Does the fat-protein meal increase postprandial glucose level in type 1 diabetes patients on insulin pump: the conclusion of a randomized study. Diabetes Technol Ther 2012; 14: 16-22.

48. Gawrecki A, Duda-Sobczak A, Zozulińska-Ziółkiewicz D, Wierusz-Wysocka B. Ocena wzrostu glikemii po posiłku białkowo-tłuszczowym u chorych na cukrzycę typu 1 leczonych za pomocą osobistej pompy insulinowej. Diabetol Prakt 2010; 1: 9-16.

49. Sieradzki J, Wierusz-Wysocka B. Cukrzyca typu 1 u dorosłych. Termedia Wydawnictwa Medyczne, Poznań 2012; 99-138.

50. Chase HP, Saib SZ, MacKenzie T et al. Postprandial glucose excursions following four methods of bolus insulin administration in subjects with type 1 diabetes. Diabet Med 2002; 19: 317-321.

51. Lee SW, Cao M, Sajid S et al. The dual-wave bolus feature in continuous subcutaneous insulin infusion pumps controls prolongued postprandial hyperglycemia better than standard bolus in type 1 diabetes. Diabetes Nutr Metab 2004; 17: 211-216. 
52. García-López JM, González-Rodriguez M, Pazos-Couselo M et al. Should the amounts of fat and protein be taken into consideration to calculate the lunch prandial insulin bolus? Results from a randomized crossover trial. Diabetes Technol Ther 2013; 15: 166-171.

53. Lindholm-Olinder A, Runefors J, Smide B, Kernell A. Postprandial glucose levels following three methods of insulin bolusing: a study in adolescent girls and in comparison with girls without diabetes. Pract Diabetes Int 2009; 26: 2110-2115.

54. Klupa T, Benbenek-Klupa T, Matejko T et al. The impact of a pure protein load on the glucose levels in type 1 diabetes patients treated with insulin pumps. Int J Endocrinol 2015; 2015: 216918. doi: 10.1155/2015/216918.

55. Smart CEM, Evans M, O'Connell S et al. Both dietary protein and fat increase postprandial glucose excursions in children with type 1 diabetes, and the effect is additive. Diabetes Care 2013; 36: 3897-3902.

56. Pańkowska E, Szypowska A, Lipka M et al. Application of novel dual wave meal bolus and its impact on glycated hemoglobin A1c level in children with type 1 diabetes. Pediatr Diabetes 2009; 10: 293-303.

57. Klupa. T, Skupień J, Cyganek K et al. The dual-wave bolus feature in type 1 diabetes adult users of insulin pumps. Acta Diabetol 2011; 48: 11-14.

58. Jones SM, Quarry JL, Caldwell-McMillan M et al. Optimal insulin pump dosing and postaprandial glycaemia following a pizza meal using the continuous glucose monitoring system. Diabetes Technol Ther 2005; 7: 233-240.

59. De Palma A, Giani E, lafusco $D$ et al. Lowering postprandial glycaemia in children with type 1 diabetes after Italian pizza 'margherita' (TyBoDi2 Study). Diabetes Technol Ther 2011; 13: 483-487.

60. Burdick JL, Chase HP, Slover RH et al. Missed insulin meal boluses and elevated hemoglobin A1c levels in children receiving insulin pump therapy. Pediatrics 2004; 113: e221-e224.

61. Olinder AL, Kernell A, Smide B. Missed bolus doses: devastating for metabolic control in CSII-treated adolescents with type 1 diabetes. Pediatr Diabetes 2009; 10: 142-148.

62. O'Connell MA, Donath S, Cameron FJ. Poor adherence to integral daily tasks limits the efficacy of CSII in youth. Pediatr Diabetes 2011; 12: 556-559.

63. American Diabetes Association. Approaches to glycemic treatment. Sec. 7. In Standards of Medical Care in Diabetes - 2015. Diabetes Care 2015; 38 (Suppl 1): S41-S48.

64. Chiang JL, Kirkman MS, Laffel LM, Peters AL. Type 1 diabetes through the life span: a position statement of the American Diabetes Association. Diabetes Care 2014; 37: 2034-2054.

65. Wolpert HA, Atakov-Castillo A, Smith SA, Steil GM. Dietary fat acutely increases glucose concentrations and insulin requirements in patients with type 1 diabetes: implications for carbohydratebased bolus dose calculation and intensive diabetes management. Diabetes Care 2013; 36: 810-816.

66. Canadian Diabetes Association Clinical Practice Guidelines Expert Committee. McGibbon A, Richardson C, Hernandez Ch, Dornan J. Canadian Diabetes Association 2013 clinical practice guidelines for the prevention and management of diabetes in Canada. Pharmacotherapy in Type 1 Diabetes. Can J Diabetes 2013; 37 (Suppl 1): S56-S60.

67. Jovanovic L, Giammattei J, Acquistapacace M et al. Efficacy comparison between preprandial and postprandial insulin aspart administration with dose adjustment for unpredicable meal size. Clin Ther 2004; 26: 1492-1497.

68. Scaramuzza AE, lafusco $D$, Santoro $L$ et al. Timing of bolus in children with type 1 diabetes using continuous subcutaneous insulin infusion (TiBoDi Study). Diabetes Technol Ther 2010; 12: 149-152.

69. Cobry EL, McFann K, Messer L et al. Timing of meal insulin boluses to achieve optimal postprandial glycemic control in patients with type 1 diabetes. Diabetes Technol Ther 2010; 12: 173-177.

70. Monro JA, Shaw M. Glycemic impact, glycemic glucose equivalents, glycemic index, and glycemic load: definitions, distinctions, and implications. Am J Clin Nutr 2008; 87: 237S-243S.

71. Kordonouri O, Hartnann R, Remus K et al. Benefit of supplementary fat plus protein counting as compared with conventional carbohydrate counting for insulin bolus calculation in children with pump therapy. Pediatr Diabetes 2012; 13: 540-544.

72. Davidson J. Should postprandial glucose be measured and treated to a particular target? Yes. Diabetes Care 2003; 6: 1911-1921.

73. Bastyr EJ, Stuart CA, Brodows RG et al. Therapy focused on lowering postprandial glucose, not fasting glucose, may be superior for lowering HbA1c. Diabetes Care 2000; 23: 1236-1241.

74. Hanefeld M, Koehler C, Schaper F et al. Postprandial plasma glucose is an independent risk factor for increased carotid intimamedia thickness in non-diabetic individuals. Astherosclerosis 1999; 144: 229-235.

75. Simmons JH, Chen V, Miller KM et al. Differences in the management of type 1 diabetes among adults under excellent control compared with those under poor control in the T1D exchange clinic registry. Diabetes Care 2013; 36: 3573-3577.

76. Katz M, Laffel L. Mortality in type 1 diabetes in the current era. Two steps forward, one step backward. JAMA 2015; 313: 35-36.

77. Writing Group for the DCCT/EDIC Research Group. Association between 7 years of intensive treatment of type 1 diabetes and long-term mortality. JAMA 2015; 313: 45-53.

78. Livingstone $\mathrm{SJ}$, Levin D, Looker $\mathrm{H}$ et al. Estimated life expectancy in Scottish cohort with type 1 diabetes, 2008-2010. JAMA 2015; 313: 37-44. 